\section{Noninvasive ventilation in acute respiratory distress syndrome: A long way ahead}

Sir,

We thank Rao et al. for their observation on our study ${ }^{[1]}$ regarding the use of noninvasive ventilation (NIV) in mild-to-moderate acute respiratory distress syndrome (ARDS) ${ }^{[2]}$ The response from Rao and Munta presents a very gloomy picture for the role of NIV in ARDS, which is not true. ${ }^{[2]}$ The judicious use of NIV has been shown to prevent endotracheal intubation in $52 \%$ of the cases of ARDS. ${ }^{[3]}$ The mortality rate in studies involving the use of NIV in ARDS is variable, depending on the patient profile. ${ }^{[3]}$ While it was $32 \%$ in the study (Thille et al.) ${ }^{\left[{ }^{[4]}\right.}$ quoted by Rao et al., it has been reported to be as high as $71 \% .{ }^{[5]}$ The authors have raised a concern regarding a delay in intubation being the primary reason for high mortality. They further suggest that earlier intubation could have avoided the deaths in our study. ${ }^{[1]}$ The median (interquartile range) time to intubation was $3(1-4) \mathrm{h}$ in our study that is far earlier than that reported in an international multicenter study on the use of NIV in ARDS. ${ }^{[6]}$ Further, without a control group of invasive ventilation, one cannot conclude from our study that the use of NIV or delay in intubation led to an increase in mortality. In addition, Rao et al. quote a retrospective study (a study design fraught with many limitations) describing the use of NIV in ARDS following esophagectomy (postsurgical patients), ${ }^{[7]}$ the patient profile being entirely different from that of our study (predominantly sepsis). Interestingly, Rao et al. claim an astonishingly low mortality rate of ARDS in their Intensive Care Unit (ICU) using pressure control ventilation (a strategy yet to establish its role in ARDS). ${ }^{[2]}$ Only two strategies have shown a reduction in mortality in patients with ARDS, namely the low tidal volume strategy using volume control ventilation and prone ventilation. ${ }^{[8,9]}$ The mortality even at best centers has been reported to be around $32 \%{ }^{[8]}$ Further, the reference by the authors where they suggest a low mortality in their ICU seems to be a review article and not an original article subjected to the rigors of a thorough peer review. ${ }^{[10]}$ It would be interesting to see if Rao et al. could replicate their observation in an original article.

\section{Financial support and sponsorship \\ Nil.}

\section{Conflicts of interest}

There are no conflicts of interest.

\section{Inderpaul Singh Sehgal, Sahajal Dhooria, Ritesh Agarwal, Dhruva Chaudhry ${ }^{1}$ Department of Pulmonary Medicine, Postgraduate Institute of Medical Education and Research, Chandigarh, 'Department of Pulmonary and Critical Care Medicine, Postgraduate Institute of Medical Sciences, University of Health Sciences, Rohtak, Haryana, India \\ Correspondence: Dr. Inderpaul Singh Sehgal, Department of Pulmonary Medicine, Postgraduate Institute of Medical Education and Research, Sector-12, Chandigarh - 160 012, India. E-mail: inderpgi@outlook.com}

\section{References}

1. Sehgal IS, Chaudhuri S, Dhooria S, Agarwal R, Chaudhry D. A study on the role of noninvasive ventilation in mild-to-moderate acute respiratory distress syndrome. Indian J Crit Care Med 2015;19:593-9.

2. Rao M, Munta K. The role of noninvasive ventilation in mild to moderate acute respiratory distress syndrome. Indian J Crit Care Med 2015;19:751-2.

3. Agarwal R, Aggarwal AN, Gupta D. Role of noninvasive ventilation in acute lung injury/acute respiratory distress syndrome: a proportion meta-analysis. Respir Care 2010; 55:1653-60. 
4. Thille AW, Contou D, Fragnoli C, Cordoba-Izquierdo A, Boissier F, BrunBuisson C. Non-invasive ventilation for acute hypoxemic respiratory failure: intubation rate and risk factors. Crit Care 2013;17:R269.

5. Rana S, Jenad H, Gay PC, Buck CF, Hubmayr RD, Gajic O. Failure of non-invasive ventilation in patients with acute lung injury: observational cohort study. Crit Care 2006;10:R79.

6. Antonelli M, Conti G, Esquinas A, Montini L, Maggiore SM, Bello G, et al. A multiple-center survey on the use in clinical practice of noninvasive ventilation as a first-line intervention for acute respiratory distress syndrome. Crit Care Med 2007;35:18-25.

7. Yu KY, Zhao L, Chen Z, Yang M. Noninvasive positive pressure ventilation for the treatment of acute respiratory distress syndrome following esophagectomy for esophageal cancer: a clinical comparative study. J Thorac Dis 2013;5:777-82.

8. Ventilation with lower tidal volumes as compared with traditional tidal volumes for acute lung injury and the acute respiratory distress syndrome. The Acute Respiratory Distress Syndrome Network. N Engl J Med 2000;342:1301-8.

9. Guerin C, Reignier J, Richard JC, Beuret P, Gacouin A, Boulain T, et al. Prone positioning in severe acute respiratory distress syndrome. N Engl J Med 2013;368:2159-68.

10. Rao M, Munta K. Acute respiratory distress syndrome- past, present and future. Curr Respir Med Rev 2015;11:231-5.
This is an open access article distributed under the terms of the Creative Commons Attribution-NonCommercial-ShareAlike 3.0 License, which allows others to remix, tweak, and build upon the work non-commercially, as long as the author is credited and the new creations are licensed under the identical terms.

\begin{tabular}{|l|l|}
\hline \multicolumn{2}{|c|}{ Access this article online } \\
\hline Quick Response Code: & Website: \\
& www.ijccm.org \\
\cline { 2 - 3 } & DOI: $10.4103 / 0972-5229.175947$ \\
\hline
\end{tabular}

How to cite this article: Sehgal IS, Dhooria S, Agarwal R, Chaudhry D. Noninvasive ventilation in acute respiratory distress syndrome: A long way ahead. Indian J Crit Care Med 2016;20:129-30. 